\title{
Analysis of Rainfall in the Locality of Babahoyo, for the Programming of Cultivation of Rice (Oryza Sativa L.)
}

\author{
Oscar Caicedo-Camposano, Professor \\ Oscar Mora-Castro, Subdecane \\ Eleonora Layana-Bajana, Professor \\ Arianna Sotomayor-Moran, Agronomic Engineer
}

Technical University of Babahoyo (UTB), Ecuador

\section{Rodolfo Barbeito-Rodríguez.}

Oceanographer- Hydrographer Engineer -Naval Academy Granma, Cuba

\begin{abstract}
The work was carried out with the objective of knowing the precipitation regime of Babahoyo, Los Ríos in Ecuador and in this way contribute to the improvement of the cropping calendar of "rainfed rice", as this information is commonly required by farmers and agricultural professionals who work as agricultural advisers. A serie of record's rainfalls were processed in about 35 years belonging to the Babahoyo's Weather Station of the National Institute of Meteorology and Hydrology situated on the premises of the Faculty of Agricultural Sciences of theTechnical University of Babahoyo (UTB), the methodology applied focuses on the identification of statistics such as the mean, standard deviation, variance, coefficient of variation, asymmetry coefficient and kurtosis coefficient; then on the basis of average is determined dry and wet periods, the frequency and the intensity in which they occur. It was found that in this town from 1980 to 2014 occurred eight dry periods and seven wet periods, that occured with a frequency of 3.4 and 3.7 years respectively. Based on the results, the wet season is defined between the months from December to May and the dry season from June to November. The sheet available average cumulative rainfall, which is determined for wet and dry periods, has the following valuables: $1001,3 \mathrm{~mm}, 3169 \mathrm{~mm}$ and an average of $2167,7 \mathrm{~mm}$. The rainfed rice in the area should be planted from the month of December, to be taken advantage of all the rain of the wet season.
\end{abstract}

Keywords: Characterization of precipitation, dry periods, wet periods, rice. 


\section{Introduction}

The city of Babahoyo, like the rest Los Rios province, presents abnormal distribution of rainfalls, the reason for this is because annually there are times with excessive rains that cause floods, causing losses in the agricultural sector and seasons in which the lack of rainfall is considered drought (Caicedo Camposano, Balmaseda Espinosa, \& Proaño Saraguro, 2015).

The agricultural production of the area of influence of the Babahoyo's Weather Station (BWS) is performed with greater intensity in the dry season, therefore, it is important to know the regime of rainfalls in the area, beause this is often a limiting factor in crop yields.

Studies on characterization of precipitation were made by (Prohaska, 1952); (Canziani, Forte Lay, \& Troha, 1992); (Ravelo, Sanz Ramos, \& Douriet Cárdenas, 2014), who characterized the seasonal precipitation regimes in some localities in Argentina and South America. On the other hand (Naranjo, 2012), had as a priority the estimate of dry periods and wet periods in the basin of El Tajo in Spain.

Rainfalls in the area of Babahoyo are presented only at a certain time of the year. The rainfalls' regime in some cities of the ecuadorian coast as Manta, La Libertad, Guayaquil, Puerto Bolívar and Quevedo, is characterized by rainfall from December to May; of those months the largest volumes of precipitation the troop in February and March, then from June to November precipitation fall below the monthly average and in certain months values are close to zero (Hernández \& Zambrano, 2007); (Gálvez \& Regalado, 2009); (Caicedo-Camposano, Cadena-Piedrahita, Alcívar-Torres, Veloz-Paredes, \& Montecé-Mosquera, 2016).

For the characterization of precipitation, it is necessary to identify the dry periods, for this, in the field of hydrology have been generated indexes of droughts, which allow you to point out and compare the influence of these, in watersheds, the same ones that have consequences such as economic, social and environmental impacts (Valiente, 2001).

It is essential to study the precipitation regime, their characteristics and trends, and with the results obtained, subsequently you can implement strategies to efficiently use the water (Sacchi, Dalla Marta, Costanzo, \& Coronel, 2002), particularly in the agricultural production, achieving with this adjust crop calendars for practices that become efficient rainfed agriculture (Meseth \& Yu, 2014), traditional practice for lack of irrigation infrastructure in the production of rice, in the village of study.

The objective of this work was to know the precipitation regime of the city of Babahoyo for the improvement of the cropping calendar of "rainfed rice", because this information is commonly required by farmers in the area and professionals, who work as technical advisers 


\section{Methodology}

The BWS is located at km 7.5 via Montalvo in the premises of the Faculty of Agricultural Sciences of theTechnical University of Babahoyo, in the city of Babahoyo, province Los Ríos, the georeferencing established by the Military Geographic Institute of Ecuador are the geographic coordinates $01^{\circ} 47^{\prime} 49^{\prime \prime}$ South Latitude and 79²0'00" West longitude, altitude of eight meters above sea level. This station is in operation and is part of the network of meteorological stations of the National Institute of Meteorology and Hydrology (INAMHI). For the determination of dry periods and wet periods, was employed a statistical method formed throughout series of time, which may be annual or periodic, these latters can be from seasonal to time zones (Naranjo, 2012). The records that were used for this work were treated as univariate series which was calculated a set of statistics such as mean, standard deviation, coefficient of variation, variance, asymmetry coefficient and kurtosis coefficient. For each wet and dry period was established, its duration, the periods in which they are presented, the periodicity, the deficit or excess, as the case may be, and the intensity. The data used were from the annual cumulative precipitation (Table 1) from the records of the rain gauge; this information rests in the archives of the INAMHI.

Table 1:Monthly precipitation BWS

\begin{tabular}{|c|c|c|c|c|c|c|c|c|c|c|c|c|c|}
\hline Years & Jan. & Feb. & Mar. & Apr. & May. & Jun. & Jul. & Aug. & Sep. & Oct. & Nov. & Dec. & Annual \\
\hline 1980 & 207,0 & 264,8 & 452,2 & 567,9 & 94,6 & 1,5 & 0,0 & 0,0 & 0,1 & 4,6 & 7,5 & 3,6 & 1603,8 \\
\hline 1981 & 195,1 & 564,2 & 403,8 & 197,3 & 3,6 & 2,5 & 8,2 & 0,6 & 0,5 & 0,4 & 1,4 & 62,0 & 1439,6 \\
\hline 1982 & 249,4 & 249,7 & 120,6 & 148,7 & 6,9 & 0,5 & 0,2 & 0,0 & 2,8 & 20,6 & 352,2 & 610,3 & 1761,9 \\
\hline 1983 & 1047,2 & 722,1 & 845,6 & 400,2 & 742,9 & 433,5 & 455,1 & 51,6 & 143,6 & 50,2 & 97,0 & 189,1 & 5178,1 \\
\hline 1984 & 25,4 & 689,6 & 565,1 & 479,6 & 6,3 & 49,2 & 1,3 & 0,3 & 7,4 & 2,8 & 27,0 & 113,0 & 1967,0 \\
\hline 1985 & 210,3 & 120,9 & 307,5 & 122,7 & 21,6 & 0,2 & 0,0 & 0,8 & 0,4 & 0,6 & 6,3 & 109,5 & 900,8 \\
\hline 1986 & 752,4 & 440,5 & 361,4 & 386,6 & 4,0 & 1,0 & 0,2 & 0,7 & 2,1 & 10,0 & 25,1 & 91,5 & 2075,5 \\
\hline
\end{tabular}




\begin{tabular}{|c|c|c|c|c|c|c|c|c|c|c|c|c|c|}
\hline 1987 & 712,9 & 960,1 & 601,3 & 566,5 & 164,7 & 0,1 & 3,1 & 4,2 & 0,7 & 3,7 & 1,2 & 31,6 & 3050,1 \\
\hline 1988 & 492,9 & 364,2 & 50,5 & 541,3 & 104,3 & 10,9 & 1,6 & 0,1 & 1,1 & 2,8 & 4,7 & 75,0 & 1649,4 \\
\hline 1989 & 522,9 & 778,1 & 775,6 & 285,2 & 22,8 & 11,1 & 1,4 & 1,4 & 0,3 & 6,7 & 7,8 & 17,4 & 2430,7 \\
\hline 1990 & 206,5 & 330,8 & 282,3 & 283,0 & 32,1 & 35,3 & 0,3 & 0,1 & 0,6 & 2,9 & 1,2 & 128,8 & 1303,9 \\
\hline 1991 & 758,9 & 758,9 & 336,9 & 96,4 & 14,9 & 0,7 & 2,2 & 0,0 & 0,4 & 1,9 & 5,7 & 119,8 & 2096,7 \\
\hline 1992 & 471,5 & 685,1 & 787,4 & 621,1 & 688,3 & 131,6 & 4,4 & 0,6 & 0,6 & 0,1 & 11,1 & 30,3 & 3432,1 \\
\hline 1993 & 225,5 & 919,6 & 518,9 & 466,4 & 84,6 & 23,3 & 0,6 & 0,6 & 0,7 & 5,1 & 1,3 & 131,3 & 2377,9 \\
\hline 1994 & 522,7 & 514,1 & 609,0 & 380,7 & 35,3 & 0,8 & 0,3 & 0,1 & 0,0 & 4,2 & 22,5 & 261,0 & 2350,7 \\
\hline 1995 & 503,9 & 323,5 & 131,0 & 279,6 & 51,5 & 1,8 & 8,4 & 1,8 & 0,3 & 1,3 & 13,9 & 39,3 & 1356,3 \\
\hline 1996 & 214,4 & 214,4 & 263,5 & 61,4 & 6,3 & 2,4 & 3,6 & 0,5 & 0,0 & 2,0 & 0,2 & 91,7 & 860,4 \\
\hline 1997 & 438,3 & 566,1 & 764,3 & 412,2 & 206,2 & 219,5 & 90,6 & 51,9 & 51,9 & 84,1 & 560,6 & 916,4 & 4362,1 \\
\hline 1998 & 761,3 & 740,7 & 812,0 & 1132,9 & 690,1 & 210,9 & 62,8 & 10,4 & 2,0 & 1,1 & 4,7 & 50,4 & 4479,3 \\
\hline 1999 & 167,0 & 501,9 & 1109,6 & 484,8 & 179,3 & 5,6 & 1,8 & 0,5 & 12,0 & 3,1 & 13,0 & 143,7 & 2622,3 \\
\hline 2000 & 222,9 & 415,7 & 732,5 & 208,5 & 209,0 & 10,4 & 0,4 & 0,5 & 8,0 & 6,9 & 0,0 & 54,2 & 1869,0 \\
\hline 2001 & 562,6 & 608,0 & 642,2 & 430,5 & 24,5 & 0,3 & 1,9 & 0,6 & 0,5 & 1,3 & 1,5 & 6,8 & 2280,7 \\
\hline 2002 & 77,1 & 540,8 & 565,2 & 551,6 & 101,0 & 5,2 & 0,2 & 0,3 & 0,4 & 13,9 & 5,9 & 6,3 & 1867,9 \\
\hline 2003 & 177,8 & 491,0 & 347,7 & 397,0 & 38,4 & 9,1 & 3,5 & 1,5 & 0,4 & 6,0 & 32,5 & 21,0 & 1525,9 \\
\hline 2004 & 105,4 & 580,7 & 418,6 & 333,0 & 77,6 & 11,9 & 0,9 & 0,0 & 4,8 & 6,3 & 0,6 & 1,6 & 1541,4 \\
\hline 2005 & 36,4 & 109,2 & 295,5 & 328,5 & 1,9 & 0,3 & 1,6 & 0,1 & 0,1 & 0,8 & 0,4 & 160,6 & 935,4 \\
\hline 2006 & 278,3 & 618,5 & 371,8 & 77,0 & 20,5 & 4,1 & 1,0 & 1,6 & 1,6 & 0,7 & 13,7 & 45,3 & 1434,1 \\
\hline 2007 & 279,4 & 243,9 & 415,2 & 349,6 & 53,6 & 17,8 & 1,3 & 0,7 & 0,2 & 3,3 & 2,0 & 47,9 & 1414,9 \\
\hline
\end{tabular}




\begin{tabular}{|c|c|c|c|c|c|c|c|c|c|c|c|c|c|}
\hline 2008 & 525,0 & 656,8 & 836,5 & 632,4 & 112,3 & 3,0 & 1,2 & 4,6 & 3,4 & 3,1 & 6,9 & 3,2 & 2788,4 \\
\hline 2009 & 526,7 & 479,7 & 341,0 & 690,0 & 54,5 & 17,5 & 0,1 & 0,0 & 0,2 & 3,1 & 0,2 & 102,2 & 2215,2 \\
\hline 2010 & 207,3 & 632,6 & 289,7 & 382,0 & 142,1 & 7,3 & 7,3 & 0,8 & 2,6 & 0,0 & 6,4 & 372,3 & 2050,4 \\
\hline 2011 & 289,4 & 386,6 & 154,3 & 524,4 & 1,9 & 31,0 & 104,4 & 0,4 & 3,6 & 0,3 & 8,6 & 57,4 & 1562,3 \\
\hline 2012 & 516,1 & 1063,2 & 1039,5 & 380,6 & 325,9 & 4,6 & 1,4 & 1,3 & 1,6 & 7,4 & 4,4 & 23,3 & 3369,3 \\
\hline 2013 & 205,0 & 571,7 & 813,2 & 334,4 & 20,2 & 3,9 & 0,0 & 0,0 & 0,0 & 2,2 & 0,6 & 2,7 & 1953,9 \\
\hline 2014 & 440,7 & 505,5 & 122,9 & 106,7 & 553,4 & 0,5 & 15,2 & 1,1 & 3,7 & 6,3 & 0,0 & 5,9 & 1761,9 \\
\hline Average & 375,3 & 531,8 & 499,6 & 389,7 & 139,9 & 36,3 & 22,5 & 4,0 & 7,4 & 7,7 & 35,7 & 117,9 & 2167,7 \\
\hline Est. Des. & 240,3 & 226,6 & 272,8 & 212,0 & 207,6 & 87,2 & 79,1 & 12,1 & 25,3 & 16,0 & 109,4 & 183,3 & 1000,7 \\
\hline Variance & 56113,4 & 49859,8 & 72309,3 & 43653,0 & 41877,2 & 7383,7 & 6085,7 & 141,8 & 621,7 & 247,3 & 11636,5 & 32638,6 & 972789,4 \\
\hline C. variation & 0,64 & 0,43 & 0,55 & 0,54 & 0,15 & 0,24 & 0,35 & 0,30 & 0,34 & 0,21 & 0,31 & 0,16 & 0,46 \\
\hline Asy. Coef. & 0,78 & 0,19 & 0,39 & 0,11 & 0,21 & 0,35 & 0,51 & 0,38 & 0,50 & 0,40 & 0,42 & 0,32 & 0,14 \\
\hline Kurt. Coef. & 0,26 & $-0,07$ & $-0,63$ & 3,14 & 3,30 & 13,16 & 28,11 & 13,86 & 26,55 & 16,96 & 17,75 & 11,38 & 1,95 \\
\hline
\end{tabular}

\section{Results and Discussion}

From the averages for each month of the year obtained in Table 1, sets the characterization of precipitation in the year as shown in Figure 1, there are observed with clarity the months that make up the wet or rainy season, coinciding this result with the behavior of the monthly rainfall studied by (Hernandez \& Zambrano, 2007); (Gálvez \& Regalado, 2009). 


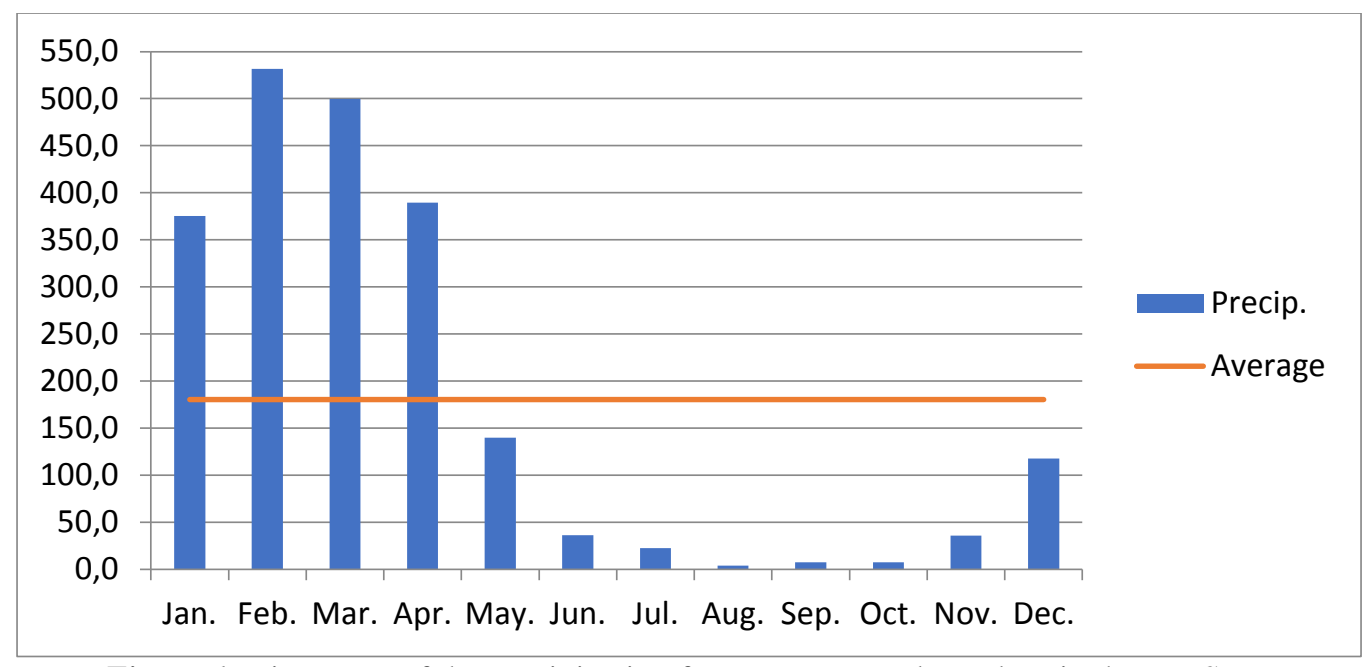

Figure 1. Histogram of the precipitacion from January to december in the BWS Source: Own elaboration

In statistical terms, the WSB has with a fairly broad length, which ensures the accurate recognition of the occurrence of dry periods and wet periods.

With the values of the annual rainfall accumulated during 35 years of registry is built Figure 2, where the path of the average, shows the years with deficits and surpluses of rainfalls. Consequently the Table 2 contains the number of differences $D_{p},(\mathrm{~mm})$, considering as level of annual average rainfall truncation $X_{0}=2167,7 \mathrm{~mm}$. This is obtained by subtracting each annual registration the average value of the accumulated annual leave. The negative results correspond to dry years, while the positive are wet years.

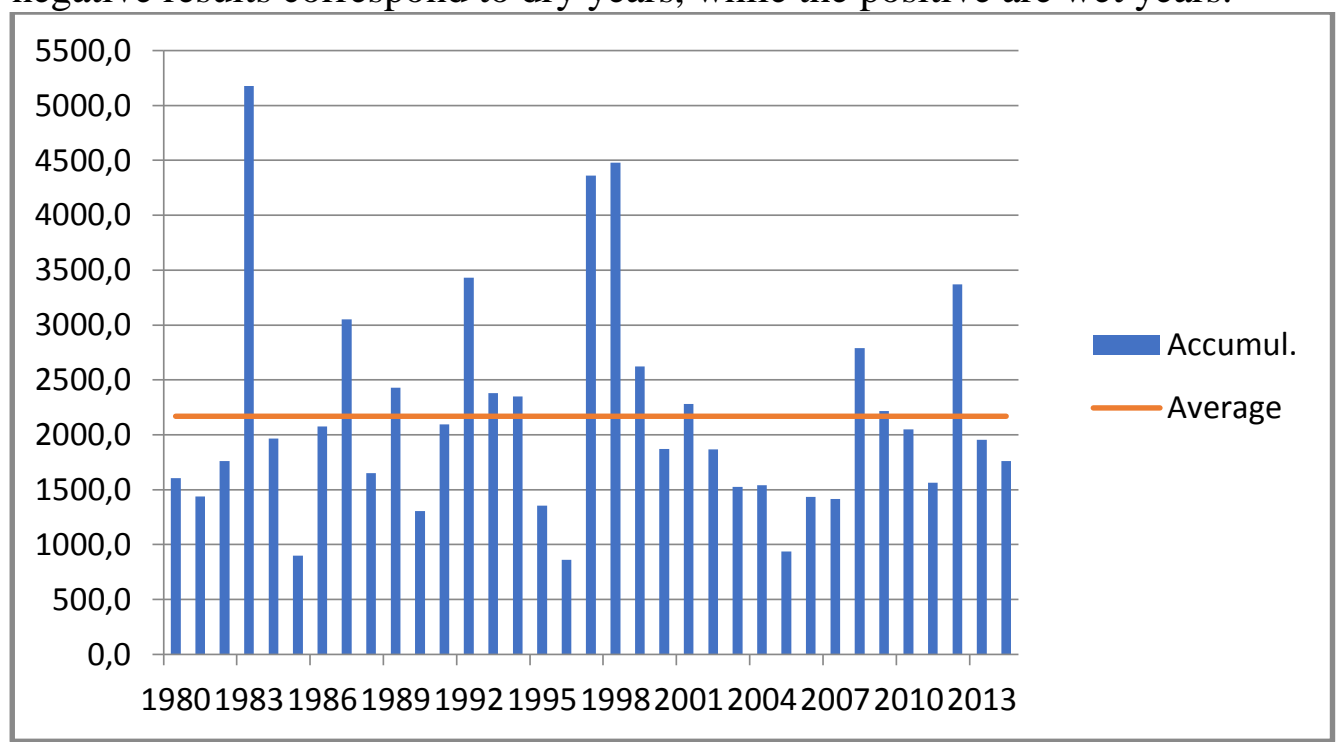

Figure 2. Histogram of annual rainfall Source: Own elaboration 
Table 2:Number of differences $D_{p}$ of the BWS

\begin{tabular}{rrrr}
\hline Year & \multicolumn{1}{l}{$D_{p}$} & Year & \multicolumn{1}{l}{$D_{p}$} \\
\hline 1980 & $-563,9$ & 1998 & 2311,6 \\
1981 & $-728,1$ & 1999 & 454,6 \\
1982 & $-405,8$ & 2000 & $-298,7$ \\
1983 & 3010,4 & 2001 & 113,0 \\
1984 & $-200,7$ & 2002 & $-299,8$ \\
1985 & $-1266,9$ & 2003 & $-641,8$ \\
1986 & $-92,2$ & 2004 & $-626,3$ \\
1987 & 882,4 & 2005 & $-1232,3$ \\
1988 & $-518,3$ & 2006 & $-733,6$ \\
1989 & 263,0 & 2007 & $-752,8$ \\
1990 & $-863,8$ & 2008 & 620,7 \\
1991 & $-71,0$ & 2009 & 47,5 \\
1992 & 1264,4 & 2010 & $-117,3$ \\
1993 & 210,2 & 2011 & $-605,4$ \\
1994 & 183,0 & 2012 & 1201,6 \\
1995 & $-811,4$ & 2013 & $-213,8$ \\
1996 & $-1307,3$ & 2014 & $-405,8$ \\
1997 & 2194,4 & & \\
\hline
\end{tabular}

Source: Own elaboration

Table 3: Characteristics of dry periods identified in the BWS

\begin{tabular}{cccccc}
\hline Dry Period & $\begin{array}{c}\text { Duration } \\
\text { (years) }\end{array}$ & Period & $\begin{array}{c}\text { Periodicity } \\
\text { (years) }\end{array}$ & $\begin{array}{c}\text { Deficit } \\
(\mathrm{mm})\end{array}$ & $\begin{array}{c}\text { Intensity } \\
\text { (mm/year) }\end{array}$ \\
\hline 1 & 3 & $1980-1982$ & & 1697,8 & 565,9 \\
2 & 3 & $1984-1986$ & 4 & 1542,8 & 514,3 \\
3 & 1 & $1988-1988$ & 4 & 882,4 & 882,4 \\
4 & 2 & $1990-1991$ & 2 & 600,8 & 300,4 \\
5 & 2 & $1995-1996$ & 3 & 418,2 & 209,1 \\
6 & 1 & $2000-2000$ & 3 & 155,9 & 155,9 \\
7 & 6 & $2002-2007$ & 1 & 4766,1 & 794,3 \\
8 & 2 & $2010-2011$ & 7 & 620,7 & 310,4 \\
9 & 2 & $2013-2014$ & 3 & 47,5 & 23,8 \\
\hline Mean & 2,4 & & 3,4 & 1192,5 & 417,4 \\
Est. Des. & 1,4 & & 1,7 & 1370,6 & 275,2 \\
Coe. Var. & 0,6 & & 0,5 & 1,1 & 0,7 \\
\hline
\end{tabular}


Table 4:Characteristics of wet periods identified in the BWS

\begin{tabular}{cccccc}
\hline Wet Period & $\begin{array}{c}\text { Duration } \\
\text { (years) }\end{array}$ & Period & $\begin{array}{c}\text { Periodicity } \\
\text { (years) }\end{array}$ & $\begin{array}{c}\text { Excess } \\
(\mathrm{mm})\end{array}$ & $\begin{array}{c}\text { Intensity } \\
\text { (mm/year) }\end{array}$ \\
\hline 1 & 1 & $1983-1983$ & & 3010,4 & 3010,4 \\
2 & 1 & $1987-1987$ & 3 & 882,4 & 882,4 \\
3 & 1 & $1989-1989$ & 2 & 263,0 & 263,0 \\
4 & 3 & $1992-1994$ & 5 & 1657,6 & 552,5 \\
5 & 3 & $1997-1999$ & 5 & 4960,6 & 1653,5 \\
6 & 1 & $2001-2001$ & 2 & 113,0 & 113,0 \\
7 & 2 & $2008-2009$ & 6 & 668,2 & 334,1 \\
8 & 1 & $2012-2012$ & 3 & 1201,6 & 1201,6 \\
\hline Mean & 0,9 & & 3,7 & 1594,6 & 1001,3 \\
Est. Des. & 0,5 & & 1,5 & 1534,1 & 901,2 \\
Coe. Var. & 1 & & 0,4 & 1,0 & 0,9 \\
\hline
\end{tabular}

Source: Own elaboration

The records examined were detected nine dry periods and eight wet periods.

A dry period occurs with a frequency of 3.4 years and an expected duration of 2.4 years; also a wet period is presented with periodicity of 3.7 years and its duration is 0.9 years, confirming the views expressed by (Naranjo, 2012) who said that the periods mentioned are cyclical.

The probability of occurrence of a dry period with a duration of 1,2 , $3,4,5$ and 6 years is $66 \%$ (6/9), 55\%, $44 \%, 33$ and $22 \%$ and $11 \%$.

The maximum recorded dry period occurred between 2002 and 2007, with an accumulated value of $4766,1 \mathrm{~mm}$, an intensity of $794.3 \mathrm{~mm} /$ year and a standard deviation in relation to the rain average annual rate of $13 \%$.

With the intensity of the dry period maximum recorded it can be determined that the available annual average between 2002 and 2007 was equivalent to: $\mathrm{Rs}=2167,7-794,3=1418,4 \mathrm{~mm}$.

The maximum intensity recorded in the dry period occurred between 1988 with $882.4 \mathrm{~mm} /$ year, with an available sheet mean anual of (Rainfall sheet) $\mathrm{Rs}=2167,7-882,4=1285,3 \mathrm{~mm}$, and a standard deviation with respect to rain annual average of $41 \%$.

The mean of the accumulated deficit is of $1192,5 \mathrm{~mm}$, for the mean duration has an intensity $417.4 \mathrm{~mm} /$ year. The available annual average is Rs $=2167,7-1192,5=975,2 \mathrm{~mm}$, or is 45 percent below the average annual rainfall.

The results in Table 3 show that a wet period of rain occurs every 3.7 years, with a mean duration of 0.9 years. The probability of a wet period with a duration of 1.2 and 3 years is $38 \%$ (3/8), $25 \%$ and $13 \%$. 
The maximum wet period registered occurred between 1997 and 1999 with an accumulated valuable of $4960,6 \mathrm{~mm}$ and intensity of $1653,5 \mathrm{~mm} /$ year. With the intensity detected it can be established that the sheet available annual average in the wet period occurred between 1997 to 1999 is: $\mathrm{Rs}=2167,7+$ $1653,5=3821,2 \mathrm{~mm}$.

The maximum intensity recorded occurred in the period of 1997 to 1999 with 1653,5 mm/year, and an annual sheet mean available $\mathrm{Rs}=2167,7$ $+1653,5=3821,2 \mathrm{~mm}$. The surplus accumulated average is $1594,6 \mathrm{~mm}$, for the average duration was detected intensity $1001,3 \mathrm{~mm} / \mathrm{year}$. The average available in the year is $\mathrm{Rs}=2167,7+1001,3=3169 \mathrm{~mm}$, or $46 \%$ above the average annual precipitation.

\section{Conclusion}

The months that define the wet season are December, January, February, March, April and May, while the months of June to November being the dry season.

The sheet available average of accumulated rainfalls determinated, for wet and dry periods have the following valuables: Rs (deficit) $=1418,4 \mathrm{~mm}$, Rs $($ average $)=2167,7 \mathrm{~mm}, \mathrm{Rs}$ (surplus) $=3169 \mathrm{~mm}$.

Depending on the frequency with which the dry and wet periods, it can be said that these show cyclicity. The most critical dry period had a duration of 4 years and was introduced in 2002 to 2007 accumulating a deficit of 4766,1 $\mathrm{mm}$, which represents the $219 \%$ of the average annual rainfall.

The cultivation of "rainfed rice" should be planted from the month of January, in this way this vegetal specie will take advantage of all the rainfall of the wet season.

\section{References:}

1. Caicedo Camposano, O., Balmaseda Espinosa, C., \& Proaño Saraguro, J. (2015). Programación del riego del banano (Musa paradisiaca) en finca San José 2, Los Ríos, Ecuador. Revista Ciencias Técnicas Agropecuarias, 24(2), 18-22.

2. Caicedo-Camposano, O., Cadena-Piedrahita, D., Alcívar-Torres, L., Veloz-Paredes, A., \& Montecé-Mosquera, F. (2016). Análisis del comportamiento de las precipitaciones en Quevedo-Ecuador, para la planificación de cultivos. European Scientific Journal, ESJ, 12(33).

3. Canziani, O., Forte Lay, J., \& Troha, A. (1992). Estacionalidad de las precipitaciones en el territorio continental argentino. Geoacta, 19, 2136.

4. Gálvez, H., \& Regalado, J. (2009). Comportamiento de las precipitaciones en la costa ecuatoriana en el 2008. Acta Oceanográfica del Pacífico, 15(1), 19-26. 
5. Hernández, F., \& Zambrano, E. (2007). Inicio, duración y término de la estación lluviosa en cinco localidades de la costa ecuatoriana. Acta Oceanográfica del Pacífico, 14(1), 7-11.

6. Meseth, E., \& Yu, J. (2014). Mejora en los calendarios de cultivo para agricultura de secano en ceja de selva. Scientia Agropecuaria, 5(4), 187-197.

7. Naranjo, M. F. (2012). Estimación de períodos húmedos y secos en la Hidrología. Revista de Educación en Ciencias e Ingeniería (UAM-I), $85,56-72$.

8. Prohaska, F. (1952). Regímenes estacionales de precipitación de Sudamérica y mares vecinos (desde $15^{\circ} \mathrm{S}$ hasta Antártida). Meteoros, 2, 66-100.

9. Ravelo, A. C., Sanz Ramos, R., \& Douriet Cárdenas, J. C. (2014). Detección, evaluación y pronóstico de las sequías en la región del Organismo de Cuenca Pacífco Norte, México. Agriscientia, 31(1), 1124.

10. Sacchi, O., Dalla Marta, N., Costanzo, M., \& Coronel, A. (2002). Caracterización de las precipitaciones en la localidad de Zavalla. Revista de Investigaciones de la Facultad de Ciencias Agrarias - UNR, 2(2), 91-103.

11. Valiente, Ó. M. (2001). Sequía: definiciones, tipologías y métodos de cuantificación. Investigaciones Geográficas, (26), 59-80. 